\title{
Lignin: a valuable feedstock for biomass pellet
}

\author{
S. M. A. Sujan ${ }^{1,2 *}$, M. A. Kashem ${ }^{2}$ and A. N. M. Fakhruddin ${ }^{1}$ \\ ${ }^{1}$ Department of Environmental Sciences, Jahangirnagar University, Dhaka-1342, Bangladesh \\ ${ }^{2}$ Institute of Fuel Research and Development (IFRD), Bangladesh Council of Scientific and Industrial Research (BCSIR), \\ Dhaka 1205, Bangladesh
}

Received: 24 February 2019

Revised: 12 May 2029

Accepted: 01 July 2019

DOI: https://doi.org/10.3329/bjsir.v55i1.46735

\begin{abstract}
Pelletization and briquettization have been extensively used for mass and energy densification of biomass. As the demand for pellets increases, the biorefinery waste lignin can be used with the conventional raw materials for pellet preparation. Sugarcane bagasse (20-40 mesh) is treated with $\mathrm{NaOH}(8 \% \& 16 \%)$ for bioethanol production and obtained lignin is used to prepare pellet along and with sugarcane bagasse (SB). SB, Lignin ${ }^{1}\left(8 \% \mathrm{NaOH}\right.$ treated SB), Lignin ${ }^{2}(16 \% \mathrm{NaOH}$ treated SB) and various composition of $\mathrm{SB}$ and Lignin $^{1}$ were used to produce pelletswith different applied pressures $(5 \mathrm{kN}, 10 \mathrm{kN}, 15 \mathrm{kN}$ and $20 \mathrm{kN})$. Pellet density and heating value were gradually increase with the applied pelletization pressure. Among the samples Lignin ${ }^{1}$ showed highest heating value at $20 \mathrm{kN}(3581.54 \mathrm{kcal} / \mathrm{kg})$. Results revealed that $5 \mathrm{kN}$ is enough to produce pellet from different composition of SB and $\operatorname{Lignin}^{1}$ and the pellet composition of SB (40\%) and Lignin $\left.160 \%\right)$ showed the highest heating value $(3456.21 \mathrm{kcal} / \mathrm{kg})$.
\end{abstract}

Keywords: Sugarcane bagasse; Alkali treatment; Lignin; Pellet; Heating value; Pressure

\section{Introduction}

In recent years biomass gaining interest not only to produce heat and power but also to reduce carbon dioxide emissions into the atmosphere. In Bangladesh lignocellulosic plants and agricultural waste biomass is available in substantial quantities, and can be utilized as sustainable energy sources (Jahan et al., 2016; Stelte et al., 2011). Energy consumption and environment concern are the key issues in recent time. A considerable amount of lignin is generated in a biorefinery, which is potential for biomaterials and biofuel (Jahan et al., 2016a, Sarkar et al., 2018). In this perspective, lignin can be a potential renewable feedstock to prepare pellet. Pellets are usually made from primary biomass materials wood residues, such as sawdust, wood shavings and wood chips, but now a days agro-residues, such as straw, sugarcane bagasse, wheat straw etc and waste products of the food industry are also used for pellet preparation (Jiang et al., 2016; Liu et al., 2016).

Pelleting and bricketting is a simple process, can use various types of waste materials. Biomass pellet has some major benefits that's are: a higher energy density, lower transportation and storage costs, prepare desired sizes and composition, which could be used as domestic and industrial purposes (Stelte et al., 2011). In lignocellulosic plant tissue, lignin can be found as deposited cell walls adjacent with cellulose and hemicellulose. It may include $15-25 \%$ of total feedstock dry matter. The lignin content in non-wood generally lower than wood and easier to separte from the plant tissue. Lignin available from biomass is an aromatic and rigid polymer and its heating value is about from 22.2 $\mathrm{MJ} / \mathrm{kg}$ to $28.5 \mathrm{MJ} / \mathrm{kg}$ (Demirbas, 2017). Lignin is a complex polymer compound contained in woody plant tissue. In sugar extraction and bioethanol production from lignocellulosic materials, it is necessary to remove lignin due to its recalcitrant nature (Wunna et al., 2017). Lignin has versatile application but it requies purification which is a costly and difficult process.

The present work aimed to study the effect of direct use of crude lignin obtained from different percentage of alkali pretreatment of sugarcane bagasse for pellet making alone and in combination with sugarcane bagasse. 


\section{Materials and methods}

\section{Materials}

Sugarcane bagasse (SB) was collected from street sugarcane juice sellers and pretreated and stored as described by Sujan et al. (2018). The dried bagasse was converted into small pieces by using a crusher (locally made crusher) and 40-60 mesh size SB, Lignin ${ }^{1}$ (Lignin from SB treated with 8\% $\mathrm{NaOH}$ ), Lignin ${ }^{2}$ (Lignin from SB treated with16\% $\mathrm{NaOH}$ ) was used in this experiment (Figure I).
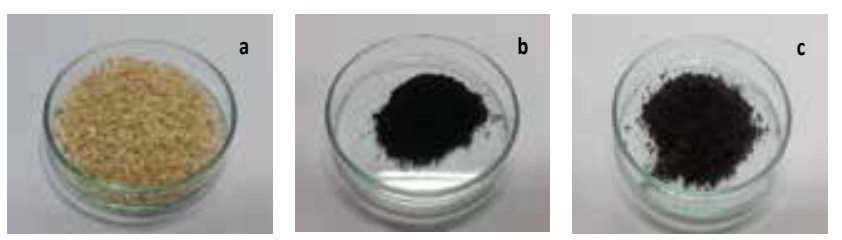

Fig. 1. (a) 40-60 mesh size $\mathrm{SB}$ (b) Lignin ${ }^{1}(8 \% \mathrm{NaOH}$ treated SB) (c) Lignin ${ }^{2}(16 \% \mathrm{NaOH}$ treated SB)

\section{Proximate analysis}

\section{Moisture and Ash content}

Moisture content of raw materials was determined by using method ASTM D 4442-07. About two grams of pretreated sample (20-40 mesh) was taken in a glass crucible and oven-dried at $105 \pm 2^{\circ} \mathrm{C}$. Weight measurement was carried out in a 3 hours interval and moisture content was expressed in percent wet basis. To determine ash content, oven-dried samples were heated in a muffle furnace at $575 \pm 25^{\circ} \mathrm{C}$ as stated in ASTM E 1755-01.

\section{Volatile matter}

Analysis of volatile matter was accomplished according to ASTM D 271-48. Raw samples of about 4grams were heated in a furnace for $7 \mathrm{~min}$ at $950 \pm 20^{\circ} \mathrm{C}$. Volatile matter is then determined by measuring the weight loss, excluding weight of moisture driven off at $105^{\circ} \mathrm{C}$.

\section{Fixed carbon}

The fixed carbon in percentage was calculated by difference between 100 and the sum of the volatile matter, moisture andash content.

\section{Ultimate analysis}

Ultimate analysis of samples was done by organic elemental analyzer (Reactor temp. $900^{\circ} \mathrm{C}$, He: $250 \mathrm{kPa}, \mathrm{O} 2: 250 \mathrm{kPa}$, TCD,Flash 2000, Thermo Scientific, USA). This instrument analyzes in accordance with the procedures stated in ASTM Standard D5291-02.

\section{Alkali treatment}

$\mathrm{SB}$ was treated with two different concentration of $\mathrm{NaOH}$. Lower \%alkali was used to produce bioethanol from SB and higher $\%$ of alkali was used to separate all possible lignin content of SB. The first experiment was carried out with $8 \%$ $\mathrm{NaOH}$ concentration, 1 hour at $80^{\circ} \mathrm{C}$ whereas the second experiment was performed with $16 \% \mathrm{NaOH}$ concentration, 1.5 hour at $150^{\circ} \mathrm{C}$. Filtrates obtained from both the experiments were dried in an oven at $105^{\circ} \mathrm{C}$ temperature for 72 hours and stored them in air tight containers. The lignin along with extractives, hemicellulose and $\mathrm{NaOH}$ obtained from $\mathrm{SB}$ by $8 \%$ and $16 \% \mathrm{NaOH}$ treatment were denoted as Lignin $^{1}$ and Lignin ${ }^{2}$, respectively.

\section{Pellet preparation}

The pellets were prepared using sugarcane bagasse $20-40$ mesh size (SB), Lignin ${ }^{1}$ (8\% NaOH treated SB), Lignin ${ }^{2}(16 \%$ $\mathrm{NaOH}$ treated $\mathrm{SB}$ ) and different composition of $\mathrm{SB}$ and lignin ${ }^{1}$ such as $\mathrm{SB}_{80}$ Lignin $_{20}^{1}$ (SB 80\% \& Lignin $^{1} 20 \%$ ), $\mathrm{SB}_{60} \operatorname{Lignin}^{1}{ }_{40}\left(\mathrm{SB} 60 \%\right.$ \& $\left.\operatorname{Lignin}^{1} 40 \%\right), \mathrm{SB}_{50} \operatorname{Lignin}_{50}{ }_{50}$ (SB $50 \%$ \& $\operatorname{Lignin}^{1} 50 \%$ ) and $\mathrm{SB}_{40}$ Lignin $_{60}^{1}\left(\mathrm{SB} 40 \%\right.$ \& Lignin $^{1}$ $60 \%$ ) (Figure 2).Universal testing machine (UTM) (FS-300kN, Testometric, England) was used for preparing pellets at $25^{\circ} \mathrm{C}$ which has carbon steel cylindrical die $(10 \mathrm{~mm}$ diameter). Each time sample was placed into the cylinder in between two carbon steel pellets. Pressure was appliedon the sample by another carbon steel pellet, a metal piston and crosshead of the UTM machine. The compression force was measured using a $300 \mathrm{kN}$ load cell, connected to a computer and data analysis software. Before each use of the die for preparing pellet was rinsed with acetone and wiped clean. Most of the time, sample was loaded in amounts less than $0.30 \mathrm{gm}$ into the die and then compressed at a rate of 2 $\mathrm{mm} / \mathrm{min}$ until the desired pelletizing pressure was reached and after $30 \mathrm{~s}$ the piston was removed. The pellets were removed from the die by removal of the backstopand pushed out by applying pressure on the pellet by the same arrangement. The pelletizing pressures used in this study were $5 \mathrm{kN}, 10 \mathrm{kN}, 15 \mathrm{kN}$ and $20 \mathrm{kN}$.
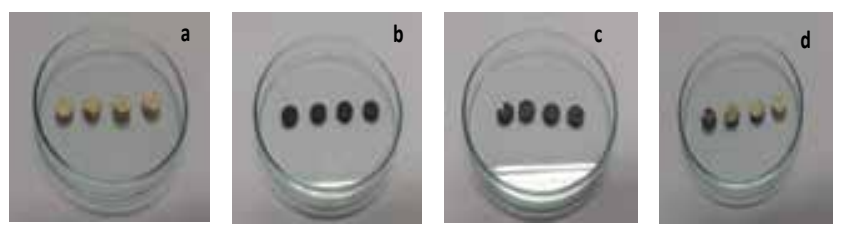

Fig. 2. Right to left (a) Bagasse pellet 4 Nos. $(20 \mathrm{kN}, 15 \mathrm{kN}$, $10 \mathrm{kN}$ and $5 \mathrm{kN})$ (b) Lignin ${ }^{1}$ pellets 4 Nos. $(20 \mathrm{kN}, 15 \mathrm{kN}$, $10 \mathrm{kN}$ and $5 \mathrm{kN}$ ) (c) Lignin $^{2}$ pellet 4 Nos. $(20 \mathrm{kN}, 15 \mathrm{kN}$, $10 \mathrm{kN}$ and $5 \mathrm{kN}$ ) (d) $\mathrm{SB} \& \operatorname{Lignin}^{1}$ pellet at $5 \mathrm{kN} 4 \mathrm{Nos}$. $\left(\mathrm{SB}_{40}\right.$ Lignin $_{60}$, $\mathrm{SB}_{80} \operatorname{Lignin}_{20}{ }_{20}$ )
$\mathrm{SB}_{50} \operatorname{Lignin}^{1}{ }_{50}$, $\mathrm{SB}_{60} \operatorname{Lignin}^{1}{ }_{40}$, 


\section{Pellet density}

The dimensions of pellets pelletized at different pressures were determined using Vernier or slide calipers. Their weights were estimated by using analytical balance capable of weighing accurately within $\pm 1.0 \mathrm{mg}$ up to four decimal places. Then pellet density at different pressures was calculated by taking the ratio of weight to volume of pellets.

\section{Heating value}

Gross heat of combustion of raw bagasse and pellets of lignin $^{1}$, lignin ${ }^{2}$ and different composition of SB and lignin ${ }^{1}$ were made at various pressures were determined according to ASTM Standard D 5865 by using oxygen bomb calorimeter (Julius Peters, Berlin- NW 21). Upon burning of the samples, the liberated heat causes the temperature to rise. The amount of heat liberated by the sample was determined by multiplying the measured temperature rise with the energy equivalent of the calorimeter. To obtain the heating value on a unit weight basis, the liberated heat was divided by the weight of the sample.

Heating value $(\mathrm{kcal} / \mathrm{kg})=\left[\mathrm{W} \times\left(\mathrm{T}_{1}-\mathrm{T}_{2}\right)\right] / \mathrm{X}$

where, $\mathrm{W}$ is denoted as the energy equivalent of the calorimeter, $\mathrm{T}_{1}-\mathrm{T}_{2}$ isthe temperature increase in a calorimeter, and $\mathrm{X}$ is mass of thesample. Energy equivalent (W) of calorimeter was found to be $10027.42 \mathrm{~kJ} /{ }^{\circ} \mathrm{C}$ by using standard benzoic acid.

\section{Results and discussion}

\section{Proximate analysis}

In proximate analysis, moisture content, ash content, volatile matter and fixed carbon of 20-40 mesh size SB, lignin ${ }^{1}$, lignin $^{2}$ were determined and is presented in Table I. Primarily analysis usually evaluate the fuel characteristicsof raw materials. The significance of higher ash content and moisture content in raw materials reduce the heating value (Sun et al., 2009). The ash content in SB was $1.75 \%$, while the same in lignin ${ }^{2}$ was $35.65 \%$. This large difference can be attributed by the presence of $\mathrm{NaOH}$.

Table I. Proximate analysis of biomass samples

\begin{tabular}{lcccc}
\hline $\begin{array}{c}\text { Name of } \\
\text { sample }\end{array}$ & $\begin{array}{c}\text { Moisture } \\
\text { content (\%) }\end{array}$ & $\begin{array}{c}\text { Ash } \\
\text { content (\%) }\end{array}$ & $\begin{array}{c}\text { Volatile } \\
\text { matter (\%) }\end{array}$ & $\begin{array}{c}\text { Fixed } \\
\text { carbon (\%) }\end{array}$ \\
\hline SB & 9.44 & 1.75 & 4.99 & 83.82 \\
Lignin $^{1}$ & 8.25 & 1.39 & 22.41 & 67.95 \\
Lignin $^{2}$ & 7.20 & 35.65 & 33.57 & 23.58 \\
\hline
\end{tabular}

\section{Ultimate analysis}

Carbon, hydrogen and oxygen are the main components in biomass. The ultimate analysis refers the elemental composition of raw materials such as carbon, hydrogen, oxygen, nitrogen and sulfur. Ultimate analysis of 20-40 mesh size SB is shown in Table II. This analysis helps to determine the quantity of air required for complete combustion, the volume and composition of combustion gases and heat of combustion of biomass which depends primarily on its carbon and hydrogen content (Poddar et al.,2014).

Table II. Ultimate analysis of 20-40 mesh size SB, Lignin ${ }^{1}$ and Lignin ${ }^{2}$

\begin{tabular}{cccccc}
\hline $\begin{array}{c}\text { Name of } \\
\text { sample }\end{array}$ & $\begin{array}{c}\text { Carbon } \\
(\%)\end{array}$ & $\begin{array}{c}\text { Oxygen } \\
(\%)\end{array}$ & $\begin{array}{c}\text { Hydrogen } \\
(\%)\end{array}$ & $\begin{array}{c}\text { Nitrogen } \\
(\%)\end{array}$ & $\begin{array}{c}\text { Sulfur } \\
(\%)\end{array}$ \\
\hline SB & 44.89 & 49.6 & 5.51 & 0.00 & 0.00 \\
Lignin $^{1}$ & 45.01 & - & 0.80 & 4.335 & 4.379 \\
Lignin $^{2}$ & 23.61 & - & 2.80 & 0.07 & 10.379 \\
\hline
\end{tabular}

\section{Heating value of biomass samples}

Heating value usually express the energy content of any types of fuel. This property depends on the biomass constituents, moisture content of materials and sometimes ash content. The heating values of raw materials are presented in Table III. Among the biomass components (extractive free) lignin plays the prominent role in higher heating values other than cellulose and hemicellulose (Demirbas, 2001). Seven samples such as SB, Lignin ${ }^{1}$, Lignin ${ }^{2}, \mathrm{SB}_{80} \operatorname{Lignin}_{20}{ }_{20}$ (SB 80\% and Lignin ${ }^{1} 20 \%$ ), SB Lignin $^{1}{ }_{40}$ (SB 60\% \& Lignin ${ }^{1} 40 \%$ ), $\mathrm{SB}_{50} \operatorname{Lignin}_{50}^{1}\left(\mathrm{SB} 50 \%\right.$ and Lignin ${ }^{1} 50 \%$ ) and $\mathrm{SB}_{40}$ Lignin $_{60}^{1}$ (SB $40 \%$ and Lignin $^{1} 60 \%$ ) have been studied in this work. Among the seven samples lignin ${ }^{1}$ hadthe highest heating value $(3581.54 \mathrm{kcal} / \mathrm{kg})$ as the percentage of carbon content is higher i.e. $45.01 \%$ (Table II) in compare with SB and lignin ${ }^{2}$. It was assumed that Lignin ${ }^{2}$ would have contained the highest heating value due to more lignin was separated from SB with the treatment of $16 \% \mathrm{NaOH}$ but practically Lignin ${ }^{2}$ has lowest heating value $(2282.02 \mathrm{kcal} / \mathrm{kg})$ due to lignin associated with some other substances.Although in all cases heating value was slightly increased with the increase of pelletizing pressure (Table III and Table VII) though $5 \mathrm{kN}$ was enough to produce pellet from all raw materials. This study also reveals that at $5 \mathrm{kN}$ applied pressure heating value gradually increase with increasing of Lignin ${ }^{1}$ percentage (20 to $60 \%$ ) in SB as presented in Table VII. 
Table III. The higher heating values of SB, Lignin ${ }^{1}$ and Lignin $^{2}$ at different pelletizing pressure

\begin{tabular}{|c|c|c|c|c|}
\hline \multirow[t]{2}{*}{ Name of sample } & \multicolumn{4}{|c|}{ Higher heating values $(\mathrm{kcal} / \mathrm{kg})$ at pelletizing pressure } \\
\hline & $5 \mathrm{kN}$ & $10 \mathrm{kN}$ & $15 \mathrm{kN}$ & $20 \mathrm{kN}$ \\
\hline SB & $\begin{array}{c}2827.23 \\
(4.0803)^{\mathrm{a}}\end{array}$ & $\begin{array}{l}2943.73 \\
(6.4676)\end{array}$ & $\begin{array}{l}3035.58 \\
(3.5995)\end{array}$ & $\begin{array}{c}3173.33 \\
(21.1707)\end{array}$ \\
\hline Lignin $^{1}$ & $\begin{array}{c}3266.78 \\
(17.1817)\end{array}$ & $\begin{array}{c}3350.62 \\
(26.7522)\end{array}$ & $\begin{array}{c}3480.11 \\
(15.8300)\end{array}$ & $\begin{array}{c}3581.54 \\
(13.3468)\end{array}$ \\
\hline $\operatorname{Lignin}^{2}$ & $\begin{array}{l}2096.94 \\
(3.0626)\end{array}$ & $\begin{array}{c}2149.29 \\
(16.9559)\end{array}$ & $\begin{array}{c}2208.35 \\
(14.6248)\end{array}$ & $\begin{array}{c}2282.02 \\
(20.8380)\end{array}$ \\
\hline
\end{tabular}

Table IV. Weight of pellets at various pressures

\begin{tabular}{|c|c|c|c|c|}
\hline \multirow[t]{2}{*}{ Name of sample } & \multicolumn{4}{|c|}{ Pellet weight $(\mathrm{g})$ at pelletizing pressure } \\
\hline & $5 \mathrm{kN}$ & $10 \mathrm{kN}$ & $15 \mathrm{kN}$ & $20 \mathrm{kN}$ \\
\hline SB & 0.2801 & 0.2772 & 0.2530 & 0.2923 \\
\hline $\operatorname{Lignin}^{1}$ & 0.2522 & 0.2794 & 0.2668 & 0.2614 \\
\hline Lignin $^{2}$ & 0.2747 & 0.2756 & 0.2682 & 0.2801 \\
\hline
\end{tabular}

Table V. Pellet sizes at various pressures

\begin{tabular}{|c|c|c|c|c|c|c|c|c|}
\hline \multirow[t]{3}{*}{ Name of sample } & \multicolumn{8}{|c|}{ Pellet sizes $(\mathrm{mm})$ at pelletizing pressure } \\
\hline & \multicolumn{2}{|c|}{$5 \mathrm{kN}$} & \multicolumn{2}{|c|}{$10 \mathrm{kN}$} & \multicolumn{2}{|c|}{$15 \mathrm{kN}$} & \multicolumn{2}{|c|}{$20 \mathrm{kN}$} \\
\hline & Hight & Diameter & Hight & Diameter & Hight & Diameter & Hight & Diameter \\
\hline SB & 4.4967 & 10.2700 & 3.9533 & 10.2700 & 3.3600 & 10.2800 & 3.6733 & 10.2700 \\
\hline Lignin $^{1}$ & 2.6100 & 10.1900 & 2.7300 & 10.2000 & 2.5300 & 10.1900 & 2.4200 & 10.1800 \\
\hline $\operatorname{Lignin}^{2}$ & 2.3100 & 10.1467 & 2.2800 & 10.1533 & 2.1600 & 10.1533 & 2.2200 & 10.1533 \\
\hline
\end{tabular}

Table VI. Pellet density $\left(\mathrm{kg} / \mathrm{m}^{3}\right)$ at different pelletizing pressures

\begin{tabular}{lcccc}
\hline Name of sample & \multicolumn{4}{l}{ Pellet density $\left(\mathrm{kg} / \mathrm{m}^{3}\right)$ at pelletizing pressure } \\
\cline { 2 - 5 } & $5 \mathrm{kN}$ & $10 \mathrm{kN}$ & $15 \mathrm{kN}$ & $20 \mathrm{kN}$ \\
\hline SB & $752.03(11.1589)^{\mathrm{a}}$ & $848.38(33.2606)$ & $908.37(13.3327)$ & $961.00(6.6785)$ \\
Lignin $^{1}$ & $1187.52(6.2740)$ & $1255.38(23.4819)$ & $1293.24(5.5734)$ & $1328.66(2.5028)$ \\
Lignin $^{2}$ & $1469.23(3.7096)$ & $1491.28(2.3534)$ & $1536.61(3.7733)$ & $1558.54(8.7574)$ \\
\hline
\end{tabular}

${ }^{a}$ Number enclosed in parenthesis are relative standard deviations for $n=3$ 


\section{Influence of pelletizing pressure on pellet density}

The pellet mass and sizes are represented in Tables IV and $\mathrm{V}$, respectively. The diameter of pellets for seven samples such as SB, Lignin ${ }^{1}, \operatorname{Lignin}^{2}, \mathrm{SB}_{80} \operatorname{Lignin}^{1}{ }_{20}$, $\mathrm{SB}_{60} \operatorname{Lignin}_{40}^{1}, \quad \mathrm{SB}_{50} \operatorname{Lignin}_{50}^{1}$ and $\mathrm{SB}_{40} \operatorname{Lignin}_{60}^{1}$ were almost same with increasing pressure (Table $\mathrm{V}$ and Table VII). Different biomass samples used for this experiment show gradual increase in pellet density with increasing pelletizing pressure from 5 to $20 \mathrm{kN}$ (Table VI). Moisture content, vacuum space and particle size were decreased with the increasing pressure of pelletization which contributes to the reduction of the radial and longitudinal expansion of pellets. Although about $0.26 \mathrm{~g}$ of $\mathrm{SB}$ and Lignin ${ }^{1}$ mixtures were taken to prepare the pellets used in density measurement, the final weights range between $0.2581 \mathrm{~g}$ and $0.2596 \mathrm{~g}$ (Table VII). This occurred mainly because of the interaction between moisture content, and temperature due to applied pressure (Carone et al., 2011). In case of unheated biomass, heat is generated during pelletization owing to friction between biomass particles and the press channel of die hole. Friction and temperature were increased within die because of increased pressure cause the water within the biomass to expel and the pellet mass decrease (Poddar et al.,2014).

\section{Conclusion}

In this study bagasse and lignin (some extractives and hemicellulose) removed from bagasse were used as valuable feedstock for biomass pelleting. Pellet density and heating value were seen to increase with the increase of pelletizing pressure $5 \mathrm{kN}$ to $20 \mathrm{kN}$. Among SB, Lignin ${ }^{1}$ and Lignin ${ }^{2}$, Lignin ${ }^{1}$ showed highest heating value at pressure ranges from $5 \mathrm{kN}$ to $20 \mathrm{kN}$ as the percentage of carbon content is higher i.e. $45.01 \%$ than others. Although for Lignin ${ }^{1} 20 \mathrm{kN}$ gave slightly higher heating value but $5 \mathrm{kN}$ is enough to prepare pellet from it. Finally, among different compositions of SB and Lignin ${ }^{1}$ pellet samples at pressure $5 \mathrm{kN}, \mathrm{SB}_{40}$ Lignin ${ }_{60}^{1}$ samplegave the highest heating value $(3456.21 \mathrm{kcal} / \mathrm{kg})$ and more compactness compared with other compositions of SB and Lignin'pellet samples. This result open a new pathway where crude lignin obtained from biorefinery waste could be used as alternative fuel.

\section{Acknowledgement}

Authors would like to acknowledge the support of the Pulp and Paper Division and Pilot Plant and Process Development Centre, BCSIR. Besides these authors would like to give thanks Mr. Mamun, BSc student, Jessore University of Science and Technology (JUST) for his assistance.

Table VII. Pellet parameters different composition of SB and Lignin ${ }^{1}$ at $5 \mathrm{kN}$ pelletizing pressures

\begin{tabular}{|c|c|c|c|c|c|c|}
\hline \multirow{2}{*}{$\begin{array}{l}\text { Name } \\
\text { sample }\end{array}$} & \multicolumn{6}{|c|}{ Pellet parameters different composition of SB and Lignin ${ }^{1}$ at $5 \mathrm{kN}$ pelletizing pressures. } \\
\hline & $\begin{array}{l}\text { Sample wt. } \\
(\mathrm{g})\end{array}$ & $\begin{array}{l}\text { Pellet wt. } \\
\text { (g) }\end{array}$ & $\begin{array}{l}\text { Hight } \\
(\mathrm{mm})\end{array}$ & $\begin{array}{c}\text { Diameter } \\
(\mathrm{mm})\end{array}$ & Pellet Density $\left(\mathrm{kg} / \mathrm{m}^{3}\right)$ & $\begin{array}{c}\text { Heating value } \\
(\mathrm{kcal} / \mathrm{kg})\end{array}$ \\
\hline $\mathrm{SB}_{80} \operatorname{Lignin}_{20}^{1}$ & 0.2600 & 0.2581 & 4.2000 & 10.3400 & $733.66(2.8340)^{\mathrm{a}}$ & $\begin{array}{c}3125.81 \\
(8.2350)^{\mathrm{a}}\end{array}$ \\
\hline $\mathrm{SB}_{60} \operatorname{Lignin}_{40}^{1}$ & 0.2602 & 0.2586 & 3.8100 & 10.3350 & $809.50(4.1125)$ & $\begin{array}{l}3301.98 \\
(6.4531)\end{array}$ \\
\hline $\mathrm{SB}_{50} \operatorname{Lignin}_{50}^{1}$ & 0.2601 & 0.2593 & 3.5100 & 10.3350 & $882.32(5.0915)$ & $\begin{array}{c}3334.00 \\
(10.2341)\end{array}$ \\
\hline $\mathrm{SB}_{40} \operatorname{Lignin}{ }_{60}^{1}$ & 0.2602 & 0.2596 & 3.3200 & 10.3350 & $925.72(9.7293)$ & $\begin{array}{c}3456.21 \\
(11.8932)\end{array}$ \\
\hline
\end{tabular}




\section{References}

ASTM D 4442-07, ASTM E 1755-01, ASTM D 271-48, ASTM D5291-02, ASTMD 5865.

Carone MT, Pantaleo A and Pellerano A (2011), Influence of process parameters and biomass characteristics on the durability of pellets from the pruning residues of Olea europaea L, Biomass and bioenergy 35(1): 402-410. DOI: $10.1016 /$ j.biombioe.2010.08.052

Demirbas A (2001), Relationships between lignin contents and heating values of biomass. Energy conversion and management 42(2): 183-188. DOI: 10.1016/ S0196-8904(00)00050-9

Demirbas A (2017), Higher heating values of lignin types from wood and non-wood lignocellulosic biomasses, Energy Sources, Part A: Recovery, Utilization, and Environmental Effects 39(6): 592-598. DOI: 10.1080/ 15567036.2016.1248798

Jahan MS, Uddin MN and Akhtaruzzaman AFM (2016), An approach for the use of agricultural by-products through a biorefinery in Bangladesh, The Forestry Chronicle, 92(4): 447-452.

Jahan MS, Haris F, Rahman MM, Samaddar, PR and Sutradhar S (2016a), Potassium hydroxide pulping of rice straw in biorefinery initiatives, Bioresource technology 219: 445-450.

Jiang, L, Yuan X, Xiao Z, Liang J, Li H, Cao L and Zeng G (2016), A comparative study of biomass pellet and biomass-sludge mixed pellet: Energy input and pellet properties, Energy Conversion and Management 126: 509-515. DOI: 10.1016/j.enconman.2016.08.035

Liu Z, Mi B, Jiang Z, Fei B and Cai Z (2016), Improved bulk density of bamboo pellets as biomass for energy production, Renewable energy 86: 1-7. DOI: 10.1016/ j.renene.2015.08.011
Poddar S, Kamruzzaman M, Sujan SMA, Hossain M, Jamal MS, Gafur MA and Khanam M (2014), Effect of compression pressure on lignocellulosic biomass pellet to improve fuel properties: Higher heating value, Fuel 131: 43-48. DOI: 10.1016/j.fuel.2014.04.061

Sarkar M, Tian C and Jahan MS (2018), Activated carbon from potassium hydroxide spent liquor lignin using phosphoric acid, TAPPI JOURNAL 17(2): 63-69.

Stelte W, Holm JK, Sanadi AR, Barsberg S, Ahrenfeldt J and Henriksen UB (2011), Fuel pellets from biomass: The importance of the pelletizing pressure and its dependency on the processing conditions, Fuel 90(11): 3285-3290. DOI: 10.1016/j.fuel.2011.05.011

Sujan SMA, Bari ML and Fakhruddin ANM (2018), Effects of physical pretreatment (crushing and ball milling) on sugarcane bagasse for bioethanol production, Bangladesh Journal of Botany 47(2): 257-264.

Sun S, Zhao Y, Ling F and Su F (2009), Experimental research on air staged cyclone gasification of rice husk, Fuel Processing Technology 90(4): 465-471. DOI: 10.1016/j.fuproc.2009.02.003

Wunna K, Nakasaki K, Auresenia JL, Abella LC and Gaspillo PD (2017), Effect of alkali pretreatment on removal of lignin from sugarcane bagasse, Chemical Engineering Transactions 56: 1831-1836. DOI: 10.3303/CET1756306 